\title{
Effects of Treating Prosopis Juliflora Pods with Multi- Enzyme, with and Without Bacterial Cultures on In-Vitro Dry Matter Digestibility (IVDMD), Fermentation Kinetics and Performance of Growing Pigs
}

DAVID MARII ( $\nabla$ davidmarii013@gmail.com )

Egerton University - Njoro Campus: Egerton University

Olivier Kashongwe Basole

Leibniz Institute of Agricultural Engineering: Leibniz-Institut fur Agrartechnik und Biookonomie eV

Anthony King'ori

Egerton University - Njoro Campus: Egerton University

\section{Research Article}

Keywords: Prosopis juliflora pod meal, Fermentation kinetics, Pig nutrition

Posted Date: August 25th, 2021

DOI: https://doi.org/10.21203/rs.3.rs-627070/v1

License: (c) (i) This work is licensed under a Creative Commons Attribution 4.0 International License. Read Full License 


\section{Abstract}

This study was conducted to determine the effects of treating Prosopis juliflora pods with multi-enzyme and bacterial cultures on in-vitro dry matter digestibility (IVDMD), fermentation kinetics and performance of growing pigs. Experiment one consisted of a pepsin-pancreatine hydrolysis method to simulate in-vitro, the pig digestive system and was followed by in-vitro gas production to assess fermentation kinetics. Samples of ground Prosopis pod meal (GPPM) were allocated to four treatments with three replicates each. Treatments included GPPM treated with multi-enzyme (Natuzyme®) (T1); Untreated (GPPM) (T2); GPPM fermented with (Lactobacillus plantarum MTD1 Ecosyl @) (T3) and GPPM treated using natural fermentation (T4). The second experiment assessed the performance of pigs fed the best treatment from experiment 1 . Thirty Landrace $\mathrm{x}$ Large white crosses of $20 \pm 2 \mathrm{Kg}$ were allotted to five treatments with six pigs each (replicates). The dietary treatments were PC -0\% GPPM + Enzyme; NC - 0\% GPPM and 0\% Enzyme; D1-10\% GPPM + Enzyme; D2- 20\% GPPM + Enzyme; and D3- 30\% GPPM + Enzyme. The completely randomized block design was used for both experiments. Enzyme treatment (T1) and T3 improved the IVDMD of the GPPM compared to T2 by $3.68 \%$ and $1.2 \%$ respectively $(p<0.05)$. Cumulative gas was highest and Tmax lowest for T1 but significantly different only to T4 $(p<0.05)$. Average daily gain and intake was highest for pigs fed GPPM up to 10\% (PC, D1). Feed conversion ratio increased with the level of GPPM in the diet. Results suggest Prosopis juliflora pods treated with enzymes can be added in pig diets up to $30 \%$.

\section{Introduction}

The animal feed industry faces the challenge of the increased price of cereals and oilseeds that are in high demand for human consumption and bioenergy production, especially in emerging markets (de Vries et al. 2012). These feed resources are critical for pig nutrition since pigs cannot efficiently utilize fibrous feed materials. In developing countries, specifically in Kenya, mainly smallholders with limited resources practice pig farming (Kagira et al. 2010; Kambashi et al. 2014). They face the challenge of the high cost of conventional feed and often resort to the use of locally available feed resources. A survey in Kenya reported that only $30 \%$ of pig farmers use commercial feeds while the remaining included some form of alternative feed material in their feeding regime (Mbuthia et al. 2014). Mature prosopis pods from Prosopis juliflora tree is such an alternative feed ingredient in Kenya (Kingori et al. 2011).

Prosopis is an invasive multipurpose tree species widely distributed within the arid and semi-arid areas of Kenya. Prosopis pods have been evaluated by several authors and were found to be of good nutritional quality for both ruminants and non-ruminants (Odero-Waitituh et al. 2016; Manhique et al. 2017). The energy content of the pods $12.8 \mathrm{MJ} / \mathrm{Kg} \mathrm{DM}$, is higher than most cereal-based milling by-products (Maize germ and wheat bran) with about $11 \mathrm{MJ} / \mathrm{Kg} \mathrm{DM}$ and slightly lesser than maize at 13.8 MJ/Kg DM (NRC 2012; Odero-Waitituh et al. 2016).However, the pods contain high levels of plant cell wall components that lower the efficiency of nutrients utilization by non-ruminants because they lack endogenous fiber digestive enzymes (de Vries et al. 2012). Relative to maize, Prosopis juliflora pods contain $69.5 \%, 53.5 \%$ and $97 \%$ more cellulose, hemicellulose and lignin content, respectively. In poultry, the high fibre content of prosopis pod meal contributes to reduction in the apparent ileal digestibility and the apparent metabolizable energy relative to maize (Al-Marzooqi et al. 2015). In pigs, poor growth rates and feed intake were reported when prosopis pod meal replaced $30 \%$ maize soybean mixture due to the effects of high fibre (Pinheiroer et al. 1993). 
Physical, chemical and biological processing have the potential to increase utilization of highly fibrous

alternative feed materials (de Vries et al. 2012). Processing methods, including the use of particle size reduction, exogenous enzymes and fermentation improves digestibility and fermentation kinetics of poor-quality feed materials (Lee et al. 2018; Zangaro et al. 2019). The use of lactic acid bacteria fermentation has not only been utilized as a means of feed preservation over the years but has been associated with a reduction of the total fibre content through hydrolysis of the neutral detergent fibre while improving the crude protein levels (Wang et al. 2018; Odero-Waitituh et al. 2020). Lyberg et al. (2006) reportedan improvement of organic matter digestibility and crude protein content after lactic acid fermentation of wheat and barley-based diets. This is supported by a recent study that concluded that use of lactic acid fermentation improved the in vitro dry matter digestibility and the fermentation kinetic of high fibrous rapeseed meal (Jang et al. 2021).

On the other hand, fibrolytic exogenous enzymes have accelerated the use of fibrous feed material due to their ability to break down the soluble and insoluble non-starch polysaccharides. Upon the breakdown of fibre and availability of the encapsulated nutrients, the resultant products are readily accessible for the intestinal microflora, thereby providing multiple beneficial effects on whole animal and animal gut intestinal health (Woyengo et al. 2016).Unfortunately, the lack of empirical evidenceon digestibility improvement of prosopispod meal subjected to pre-treatment methods remains a hindrance to their utilization inpig production in Kenya.

We therefore, hypothesised that pre-treatment of prosopis pod meal with exogenous enzyme or fermentation could improve in-vitro digestibility and fermentation kinetics, hence pig performance. The objective of the study was twofold: i) to evaluate the most suitable pre-treatment method of prosopis pod meal using in-vitro digestibility; ii) to determine the effects of increasing levels of pre-treated prosopis pod meal in diets of growing pig diets on growth performance.

\section{Materials And Methods Study Site}

The in-vitro experiment was conducted at Egerton University, Animal Nutrition laboratory. The University is situated at $0^{\circ} 23 \rrbracket \mathrm{S}, 35^{\circ} 55 \rrbracket \mathrm{N}$ within Njoro Sub-County, Nakuru County. The altitude is 1800 meters above sea level with an average annual rainfall of 900-1,200 $\mathrm{mm}$. The area has average daily temperatures ranging from $17^{\circ} \mathrm{C}-22^{\circ} \mathrm{C}$ (Egerton University Department of Agriculture Engineering, Metrological station 2018). The feeding trial was conducted at a commercial pig breeding farm in Molo Sub-County, Nakuru County Kenya. The area is located at $0^{\circ} 3598$ South and $0^{\circ} 3515 \nabla$ Eastwith an elevation of $2400-3100 \mathrm{~mm}$ above sea level and an average annual rainfall of $1200-1500 \mathrm{~mm}$.

\section{Experiment 1: In-vitro dry matter digestibility}

Preparation of experimental treatment and experimental design

Mature Prosopis pods were collected from Marigat Sub-County located 0 20'N and 35 37'E (FAO, 1992) by handpickingfrom the ground underneath the prosopis trees after vigorously shaking. The pods were dried, sorted then milled (Choge et al. 2006) and used in the preparation of the treatments. There were four treatments with three replicates each, arranged in a completely randomized design; T1: GPPM treated with an enzyme 
(Natuzyme®) T2: Untreated GPPM (Control) T3: GPPM fermented with lactic acid bacteria inoculum (Lactobacillus plantarum) T4: GPPM treated using natural fermentation

Natuzyme® (Bioproton PTY Ltd, Australia) is a multi-enzyme complexin powder form and contains 12,000 units/g of xylanase, 6,000 units/g of cellulase, 1,500units/gputed using the formula by Bauer e of phytase, 700 units/g of beta-glucanase, 700 unit/g protease and 400 unit/g of alpha-amylases. The enzyme was added to the samples of GPPM in triplicates enzyme at the rate of $350 \mathrm{mg} / \mathrm{kg}$ of feedstuff on a dry matter basis following the manufacturer's instructions and recommendations and mixed thoroughly.

Naturally fermented Prosopis meal was prepared by mixing $1 \mathrm{~kg}$ mature GPPM with distilled water at a ratio of $1: 2.75$ (wt. / vol) in triplicate. The mixture was then incubated at room temperature $\left( \pm 22^{\circ} \mathrm{C}\right)$ for 7 days using $2 \mathrm{~kg}$ plastic bottles (Jørgensen et al. 2010). The plastic bottles were sealed tightly to create anaerobic conditions. After 7 days, the $\mathrm{pH}$ of individual samples was recorded using a portable $\mathrm{pH}$ meter ( $\mathrm{pH} / \mathrm{ORP} /$ Temperature Combo Tester - HI98121 HANNA instruments) and a sample was subjected to proximate analysis. A similar procedure was applied for inoculation fermentation but in this case, a single strain of commercial Lactobacillus plantarum-MTD1 (Ecosyl® Products, Ltd., Stokesley, England) as the starter culture and applied at the rate of 1 $\times 10^{6} \mathrm{cfu} / \mathrm{g}$ of GPPM. A sample was also collected for proximate analysis. The $\mathrm{pH}$ of individual samples was measured and recorded using a digital hand-held $\mathrm{pH}$ meter ( $\mathrm{pH} / \mathrm{ORP} /$ Temperature Combo Tester - HI98121 HANNA instruments).

\section{Proximate Analysis}

The proximate analysis conducted on the samples included dry matter determination by drying in a hot air oven at $105^{\circ} \mathrm{C}$ for $24 \mathrm{~h}$ (method 934.01; AOAC, 1990), Ash by burning samples in a muffle furnace at $550^{\circ} \mathrm{C}$ for $8 \mathrm{~h}$ (method 942.05; AOAC, 1990), Ether Extract Soxhlet method(using ether) (method 920.39; AOAC, 1990). Total nitrogen for crude protein $(\mathrm{N} \times$ 6.25) determination was obtained using the micro-Kjeldahl method (method 954.01; AOAC, 1990). Constituents of the cell wall, Neutral Detergent Fiber (NDF) and Acid Detergent Fiber (ADF), were determined using the Van Soest method (Van Soest et al. 1991). Hemicellulose was determined as a difference between the Neutral Detergent Fiber (NDF) and the Acid Detergent Fiber (ADF).

\section{Enzymatic Pre-Digestion of Ground Prosopis pod meal}

To simulate the digestive process in the pigs' stomach and intestines an in-vitro digestibility trial was conducted according to Boisen and Fernhdez (1997). Ground feed sample of $0.4 \mathrm{~g}$ was weighed and placed in a $100 \mathrm{ml}$ conical flask. Sodium phosphate buffer solution, $200 \mathrm{ml}(0.1 \mathrm{M}, \mathrm{pH} 6.0)$ was added to the flask and carefully mixed with the sample by stirring. To simulate the stomach digestive process, $80 \mathrm{ml}$ of $0.2 \mathrm{M} \mathrm{HCl}$ was added and the $\mathrm{pH}$ adjusted to 2.0 with $1 \mathrm{M} \mathrm{HCl}$ or $1 \mathrm{M} \mathrm{NaOH}$ solutions. This was followed by addition of prepared $5 \mathrm{~mL}$ pepsin porcine grade enzyme with 4x USP activity (Pepsin from porcine gastric mucosa powder, $\geq 250 \mathrm{units} / \mathrm{mg}$ solid (CSigma-Aldrich Corp., St. Louis, MO, USA) containing $1 \mathrm{mg}$ pepsin per $\mathrm{ml} 0.02 \mathrm{M} \mathrm{HCl}$. To each conical flask, 2ml Chloramphenicol C-0378; (Sigma-Aldrich Corp., St. Louis, MO, USA) and 0.5g/100ml ethanol was added to inhibit bacterial growth. The flasks were closed and incubated in a water bath at $39^{\circ} \mathrm{C}$ and stirred continuously for 2 hours.Afterwards, $80 \mathrm{ml}$ of phosphate buffer $(0.2 \mathrm{M}, \mathrm{pH} 6.8)$ and $20 \mathrm{ml}$ of $0.6 \mathrm{M} \mathrm{NaOH}$ were added. The $\mathrm{pH}$ was adjusted to 6.8 using $1 \mathrm{M} \mathrm{HCl}$ or $1 \mathrm{M} \mathrm{NaOH}$ to provide a stable environment for intestinal enzymes to thrive. To the mixture, $10.6 \mathrm{ml}$ of artificial pancreatin P-1750 Sigma-Aldrich Corp., St. Louis, MO, USA containing $100 \mathrm{mg} / 1$ litre buffer was added and incubated at $39^{\circ} \mathrm{C}$ with continuous stirring for 4 hours. The 
residues were filtered through a nylon bag (pores size of $(42 \mu \mathrm{m})$ washed with distilled water, followed by washing two times using $20 \mathrm{ml}, 95 \%$ ethanol, and $20 \mathrm{ml}, 99.5 \%$ acetone. The residues were dried in an oven at $70^{\circ} \mathrm{C}$ for 12 hours and weighed.

\section{In-vitro Fermentation Phase}

The rate of fermentation of the hydrolysed substrate was assessed in-vitro by the cumulative gas production technique adapted to the pig by Bindelle et al. (2007). A $200 \mathrm{mg}$ sample was used for the third step of this procedure involving microbial fermentation.

\section{Donor Animals}

The donor animals were three large white barrows with an average weight of $25 \pm 3 \mathrm{~kg}$. Pigs were fed a diet containing prosopis pods for 7 days to allow for the adaptation to the diet (Table 1). The pig's diet contained no antibiotics. Faecal samples were collected directly from the rectum of the pig and immediately placed in a flask flushed with $\mathrm{CO}_{2}$ to avoid exposure to aerobic condition and kept in a water-bath at $39^{\circ} \mathrm{C}$ until the time of use. The faeces of the three pigs were pooled together in equal amounts to reduce within animal variation.

Table 1

Diet containing Prosopis juliflora pod meal (g/100g)

\begin{tabular}{|ll|}
\hline Ingredients & Quantity in $\mathbf{g} / \mathbf{1 0 0 g}$ \\
\hline Maize & 60 \\
\hline Soybean meal & 21.4 \\
\hline Fishmeal (Omena) & 2 \\
\hline Ground Prosopis juliflora pod meal & 12 \\
\hline Vegetable oil & 2 \\
\hline Di-calcium phosphate & 2 \\
\hline Lysine & 0.2 \\
\hline Methionine & 0.2 \\
\hline Vitamin and mineral premix & 0.1 \\
\hline lodized salt & 0.1 \\
\hline Chemical composition & \\
\hline ME(Mj/Kg) & 13.2 \\
\hline Crude protein & 17.25 \\
\hline *Vitamin premix: Vitamin and mineral premix: vitamin A 8,000 IU; vitamin D3 2,000; vitamin E 37.5 mg; \\
$\begin{array}{l}\text { vitamin K-3 0.925 mg; vitamin B2 8.43 mg; } ; \text { vitamin B12 0.04 mg; nicotinic acid 34.5 mg; pantothenic acid 26 } \\
\text { mg: 450 mg Fe; 400 mg Cu; 250 mg Zn; 150 mg Mn; 0.5 mg l; 0.25 mg Se: Omena (Rastrineobola argentea) }\end{array}$ \\
\hline
\end{tabular}




\section{Inoculum Preparation and Incubation}

The faecal mixture was blended to homogenise then filtered through double-layered cheese cloth. The filtrate was mixed at a ratio of 1 part filtrate to 20 part buffer solution on a (volume/volume basis (Bauer et al. 2001). The buffer solution composed of micro and macro minerals, reducing solution and carbonate buffer (Menke et

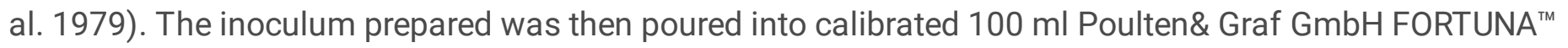
Precision Gas Syringe containing $200 \mathrm{mg}$ substrate in a thermostatically controlled water bath at $39^{\circ} \mathrm{C}$. The syringe pistons were lubricated using oil to allow ease of movement during gas measurement throughout the entire process. The whole process was carried out in anaerobic conditions by continuously bubbling of $\mathrm{CO}_{2}$. Two syringes containing the inoculum only were used as blanks. Each treatment had three replicates and the amount of gas produced during fermentation was measured at $0,2,5,8,12,16,20,24,30,36,48$ and 72 hours. The total gas produced at a particular period was computed as the total increase in volume minus the volume of gas recorded in the blank. The experimental scheme was as follows: 2 runs $\times 4$ treatment groups $\times 3$ replicate + 2 blanks (contained inoculum only)

\section{Experiment two: in vivo evaluation}

\section{Management of experimental animals and experimental design}

Experimental animals used were 15 barrows and 15 gilts with an average weight of $20 \pm 2 \mathrm{Kgs}$ which were crosses between Landrace and Large white. They were randomly allotted to the five treatment diets in a randomised complete block design with sex being the blocking factor. The experimental animals were placed in pens with concrete floors $(3 \mathrm{~m} \times 3 \mathrm{~m})$ that had dry wood shavings as beddings. The pigs used for the experiment were fed on the experimental diets for 7 days for adaptation before the beginning of the data collection period of 35 days.

\section{Experimental diets}

The pigs used were allowed ad-libitum access to experimental diets and water. The experimental animals were fed from concrete troughs while water was provided ad libitum using drinking nipples. The composition of the experimental diets are shown in Table 1.These were PC = diet containing 0\% GPPM and 0.035\% Enzyme, NC = diet containing 0\% GPPM and 0\% Enzyme, D1 = diet containing 10\% GPPM and 0.035\% Enzyme, D2 = diet containing 20\% GPPM and 0.035\% Enzyme and D3 = diet containing 30\% GPPM and 0.035\% Enzyme. The diets were formulated using maize germ, wheat bran, sunflower seed meal, fishmeal-Omen (Rastrineobola argentea) and ground prosopis pod meal (GPPM). Natuzyme ${ }^{\circledR}$ was included at the rate of $350 \mathrm{mg} / \mathrm{kg}$ of feed in dry form as per the manufacturer's instructions and recommendations.Diets were formulated to meetthe nutrient requirements of growing pigs (NRC 2012). 
Table 2

Composition of the experimental diets $(\mathrm{g} / 100 \mathrm{~g})$ and their chemical composition

\begin{tabular}{|c|c|c|c|c|c|}
\hline \multirow{2}{*}{$\begin{array}{l}\text { Ration composition } \\
(\mathrm{g} / 100 \mathrm{~g})\end{array}$} & \multicolumn{5}{|c|}{ Treatments } \\
\hline & PC & NC & D1 & D2 & D3 \\
\hline Wheat bran & 15.0 & 15.0 & 8.50 & 4.00 & 2.80 \\
\hline Maize germ & 53.20 & 53.20 & 48.50 & 42.40 & 32.50 \\
\hline Vegetable Oil & 5.0 & 5.0 & 5.0 & 5.0 & 5.0 \\
\hline GPPM & 0.0 & 0.0 & 10.0 & 20.0 & 30.0 \\
\hline Fishmeal & 6.0 & 6.0 & 5.50 & 5.0 & 5.0 \\
\hline Sunflower seed cake & 17.5 & 17.5 & 19.0 & 20.0 & 21.0 \\
\hline Lysine & 0.90 & 0.90 & 0.90 & 0.90 & 0.90 \\
\hline Methionine & 0.50 & 0.50 & 0.50 & 0.50 & 0.50 \\
\hline DCP (granular 24\%) & 0.50 & 0.50 & 0.50 & 0.50 & 0.50 \\
\hline Limestone & 0.85 & 0.85 & 0.85 & 0.85 & 0.90 \\
\hline lodized Salt & 0.25 & 0.25 & 0.25 & 0.25 & 0.25 \\
\hline Vitamin Premix* & 0.25 & 0.25 & 0.25 & 0.25 & 0.25 \\
\hline Mycotoxins Binder & 0.10 & 0.10 & 0.10 & 0.10 & 0.10 \\
\hline Natuzyme® enzyme & 0.035 & 0.0 & 0.035 & 0.035 & 0.035 \\
\hline \multicolumn{6}{|l|}{ Nutrients analysis } \\
\hline Dry matter & 88.35 & 88.35 & 88.75 & 88.52 & 90.47 \\
\hline Crude Protein(CP) & 17.01 & 17.01 & 17.02 & 17.00 & 17.01 \\
\hline Ether Extracts & 7.90 & 7.90 & 6.93 & 5.71 & 6.51 \\
\hline Ash & 8.27 & 8.32 & 8.33 & 12.33 & 13.11 \\
\hline NDF & 32.63 & 32.63 & 34.38 & 35.63 & 37.13 \\
\hline ADF & 11.12 & 11.10 & 12.60 & 13.65 & 16.94 \\
\hline GE(MJ/kg DM) & 17.10 & 17.10 & 16.90 & 16.80 & 16.90 \\
\hline
\end{tabular}

PC $=0 \%$ GPPM and 0.035\% Enzyme per kg of diet; NC = 0\% GPPM and 0\% Enzyme per kg of diet; D1 = 10\% GPPM and $0.035 \%$ Enzyme per $\mathrm{kg}$ of diet, D2 $=20 \%$ GPPM and $0.035 \%$ Enzyme per $\mathrm{kg}$ of diet, D3 = 30\% GPPM and $0.035 \%$ Enzyme per kg of diet; GPPM Ground Prosopis Pod meal; *Vitamin and mineral premix: vitamin A 8,000 IU; vitamin D3 2,000; vitamin E 37.5 mg; vitamin K 30.925 mg; vitamin B2 8.43 mg; vitamin B12 0.04 mg; nicotinic acid 34.5 mg; pantothenic acid 26 mg: 450 mg Fe; 400 mg Cu; 250 mg Zn; 150 mg Mn; 0.5 mg l; 0.25 mg Se CP = Crude Protein; NDF = Neutral detergent fiber; ADF = acid detergent fiber; GE = Gross energy. 
Individual pig body weight from each pen was recorded every week using a digital weighing scale Generic LCD Weighing Scale $50 \mathrm{~kg}$ Portable Hanging Balance with 10 grams accuracy. The weekly weights recorded were used to compute the average daily gain. Feed was offered at 0800 am while refusals were collected during the next day prior to feeding. The refusals were weighed using a digital weight balance then used to compute daily feed intake. Average daily gain and daily feed intake were used to compute the feed conversion ratio. The formulae (1, 2 and 3 ) show the equations used to calculate the production performance:

Average daily gain $(\mathrm{ADG})$ in $\mathrm{kg} /$ day $=\frac{\text { (Final Weight }- \text { Initial Weight })}{7 \text { days }}$

Daily feed intake $=$ Feed offered $(\mathrm{kg})-$ Feed refusal $(\mathrm{kg})$

FCR $=$ Feed intake $/$ Weight gain

\section{Statistical Analysis and calculations}

In-vitro total tract digestibility (IVDMD) of dry matter (DM) was computed using the following formulae (Boisen\& Fernandez, 1997)

$$
\text { DM digestibility }=\left(\frac{D M_{I n}-D M_{R S}}{D M_{I n}}\right) \times 100
$$

$\mathrm{DM}_{\mathrm{In}}$ and $\mathrm{DM}_{\mathrm{RS}}$ are the initial (DM) and residual (DM) respectively

Gas accumulation curves recorded during the 72 hours of fermentation was modified according to the monophasic model (Groot et al. 1996).

$$
G=\frac{A}{\left[1+\frac{B^{c}}{t^{c}}\right]}
$$

Where,

$\mathrm{G}(\mathrm{mL} / \mathrm{g} \mathrm{DM})=$ the amount of gas produced per gram of Dry matter (DM) incubated, at time $T$ after incubation, $A(\mathrm{~mL} / \mathrm{g} D M)=$ the asymptotic gas production, $B(h)=$ the time after incubation at which half of the asymptotic amount of gas has been formed, $\mathrm{C}=$ constant determining the sharpness of the switching characteristic of the profile.

Rmax the maximum rate of gas production $\left(\mathrm{ml} \mathrm{g}^{-1} \mathrm{xh}\right.$ ) and $\mathrm{T}_{\text {max }}$, the time at which $\mathrm{R}_{\max }$ is accomplished was computed using the formula by Bauer et al. (2001).

$$
\begin{aligned}
& R \max =\left[A \times\left(C^{B}\right) \times B \times\left(T \max { }^{(-B-1)}\right)\right] /\left[1+\left(C^{B}\right) \times\left(\operatorname{Tmax}^{(-B)}\right)\right]^{2} \\
& T \max =C \times\left[((B-1) /(B+1))^{\left(\frac{1}{B}\right)}\right]
\end{aligned}
$$


Data for the in-vitro experiment was analysed with on IBM SPSS Statistics version 22. Assumption for normality and homogeneity of variance of the data was checked using Shapiro-Wilk and Levenes test statistics respectively with data assumed to be normal when $(p>0.05)$. The IVDMD during hydrolysis, total gas production and fermentation kinetics were analysed using the mixedmodel procedure. Mean separation was conducted using Tukey HSD (Honest Significant Difference) test at 0.05 level of significance (means were considered different if $(p<0.05)$. Application of Excel solver in Microsoft excel was used in curve fitting and in the computation of fermentation kinetics. The statistical model used for the experiment is,

$$
\mathrm{Y}_{i k j}=\mu+\mathrm{T}_{i}+G_{k}+\varepsilon_{\mathrm{ikj}}
$$

where;

$Y_{\mathrm{ikj}}$-Observation on the dependent variables, $\mu$-overall mean, $\mathrm{T}_{\mathrm{i}}$-Fixed effect due to the $\mathrm{i}_{\text {th }}$ treatment, $\mathrm{G}_{\mathrm{k}}$ Random effect due to trial, $\mathrm{e}_{\mathrm{ikj}}$-the random error

For experiment two experiment data was analysed using SAS 9.0 (2002) using a two-way analysis of variance. Mean separation was conducted using Tukey's HSD (Honest Significant Difference) test at 0.05 level of significance (means were considered different if $p<0.05$. Initial weight of the pigs was fitted as a covariate while sex was used as a blocking factor.

The model used was:

$$
Y_{i j k}=\mu+T_{i}+\beta_{\mathrm{k}}+\mathrm{S}_{f}+\varepsilon_{\mathrm{ijk}}
$$

where; $Y_{i j k}=$ response variable of interest (ADG, FCR), $\mu$ - population mean, $T_{i-}$ fixed $i_{t h}$ treatment effect (PC, NC, $D 1, D 2$ and D3), $S_{f}$-fixed effect of sex (gilts and barrows) $\beta_{k}$ - fixed effect of initial weight used as a covariate.

\section{Results}

Nutritional composition of GPPM after being subjected to the different treatments are shown in Table 3. Crude protein was higher following fermentation $(15.5 \mathrm{~g} / 100 \mathrm{~g}$ and $16.4 \mathrm{~g} / 100 \mathrm{~g}$ for natural and inoculated, respectively) than enzyme treatment and control (14.5). NDF was also lower for fermented GPPM (41.5 and 43.41) for T3 and $\mathrm{T} 4$, respectively. The $\mathrm{pH}$ values for natural fermented and Lactobacillus plantarum inoculated GPPM were 4.6 and 4.4 respectively.

Table 3. Nutrients composition of GPPM treated with enzyme, fermented naturally and fermented with Lactobacillus plantarum-MTD1 (Ecosyl囚) 


\begin{tabular}{|lllll|}
\hline $\begin{array}{l}\text { Nutrientcomponents (g/100g) } \\
\text { in DM basis }\end{array}$ & $\begin{array}{l}\text { Natuzyme® multi- } \\
\text { enzyme GPPM (T1) }\end{array}$ & $\begin{array}{l}\text { Unfermented } \\
\text { GPPM (T2) }\end{array}$ & $\begin{array}{l}\text { Inoculated } \\
\text { fermentation } \\
\text { (T3) }\end{array}$ & $\begin{array}{l}\text { Natural } \\
\text { fermentation } \\
\text { (T4) }\end{array}$ \\
\hline Organic Matter & 94.35 & 94.35 & 94.15 & 93.96 \\
\hline Ash & 5.65 & 5.65 & 5.85 & 6.04 \\
\hline Ether Extract & 1.34 & 1.34 & 1.26 & 1.17 \\
\hline Crude protein & 14.48 & 14.48 & 15.50 & 16.40 \\
\hline NDF & 47.41 & 47.41 & 41.50 & 43.41 \\
\hline ADF & 27.13 & 27.13 & 23.35 & 26.5 \\
\hline Carbohydrates & 78.52 & 78.52 & 77.37 & 76.39 \\
\hline Crude fibre & 31.92 & 31.92 & 26.08 & 26.31 \\
\hline Hemicellulose & 20.28 & 20.28 & 18.15 & 16.91 \\
\hline
\end{tabular}

NDF: Neutral Detergent fibre, ADF: Acid detergent fibre.

\section{In-vitro digestibility of untreated, enzyme-treated, and Lactobacillus Plantarum fermented GPPM}

Enzyme treatment (T1) and inoculation using Lactobacillus Plantarum (T3) resulted to a higher and significant IVDMD compared to natural fermentation (T4). There was a $3.68 \%$ increase in IVDMD (Fig. 1) after treating the pods with the multi-enzyme $(\mathrm{T} 1)(52.81 \pm 1.17)$, relative to the untreated $(\mathrm{T} 2)(49.13 \pm 2.14)$. There was no significant difference in digestibility of $\mathrm{T} 2$ and $\mathrm{T} 3$.

\section{Fermentation kinetics}

The cumulative gas curve shows that T1 $(18.4 \mathrm{DM} / \mathrm{ml})$ and T2 $(17.8 \mathrm{DM} / \mathrm{ml})$ had the highest gas production, while T3 $(14.3 \mathrm{DM} / \mathrm{ml})$ had the lowest. This trend was observed from $8 \mathrm{hrs}$ to $72 \mathrm{hrs}$.

Results of fermentation kinetics of the experimental treatments are presented in Table 4. Treatment 4 (13.429 \pm 1.63$)$ had the overall lowest cumulative gas produced $\mathrm{G}(\mathrm{ml} / \mathrm{g} \mathrm{DM})$ after $72 \mathrm{hrs}$ in contrast to T1 (18.502 \pm 1.27 ) which had the highestcumulative gas produced G (ml/g DM) However, $\mathrm{T} 1, \mathrm{~T} 2$ and $\mathrm{T} 3$ were not significantly different $p>0.05$ (Table 4). Rmax, which represents the rate of gas production, was significantly affected by pre-treatment methods. Enzyme-treated GPPM (T1) had the highest rate of gas production $(0.786 \pm 0.09)$, while naturally fermented pod meal T4 had the lowest rate $(0.425 \pm 0.04)$. The rate of gas production was similar between enzyme-treated (T1) and control group (T2). On the other hand, $\mathrm{T}_{\mathrm{MAX}}$ representing the time at which the maximum rate of gas production was achieved was significantly different $(p<0.05)$ with enzyme treatment and untreated prosopis pod meal being different from natural fermented prosopis pod meal. The $\mathrm{pH}$ was not significantly different across the different treatment $p>0.05$.

Table 4: Fermentation kinetics of fermented untreated and enzyme treated Prosopis pod meal 


\begin{tabular}{|lllll|}
\hline \multicolumn{5}{|c|}{ Treatments } \\
\hline Parameters & T1 (mean \pm SE) & T2(mean \pm SE) & T3(mean \pm SE) & T4(mean $\pm S E)$ \\
\hline$G(m l / g ~ D M)$ & $18.502^{\mathrm{a}} \pm 1.27$ & $17.744^{\mathrm{a}} \pm 1.48$ & $16.535^{\mathrm{ab}} \pm 2.19$ & $13.429^{\mathrm{b}} \pm 1.63$ \\
\hline $\mathrm{A}$ & $22.194^{\mathrm{a}} \pm 2.26$ & $19.722^{\mathrm{ab}} \pm 1.84$ & $23.220^{\mathrm{a}} \pm 4.63$ & $15.287^{\mathrm{b}} \pm 2.30$ \\
\hline $\mathrm{C}$ & $1.488 \pm 0.15$ & $1.734 \pm 0.22$ & $1.946 \pm 0.48$ & $2.091 \pm 0.23$ \\
\hline $\mathrm{B}$ & $20.34^{\mathrm{b}} \pm 1.53$ & $18.361^{\mathrm{b}} \pm 1.01$ & $33.988^{\mathrm{a}} \pm 6.76$ & $22.019^{\mathrm{ab}} \pm 1.74$ \\
\hline $\mathrm{T}_{M A X}($ hrs. $)$ & $5.149^{\mathrm{b}} \pm 1.84$ & $7.911^{\mathrm{b}} \pm 1.01$ & $13.014^{\mathrm{ab}} \pm 5.68$ & $19.069^{\mathrm{a}} \pm 1.22$ \\
\hline $\mathrm{R}_{\mathrm{MAX}}$ & $0.786^{\mathrm{a}} \pm 0.09$ & $0.677^{\mathrm{a}} \pm 0.04$ & $0.493^{\mathrm{b}} \pm 0.08$ & $0.425^{\mathrm{b}} \pm 0.04$ \\
\hline $\mathrm{pH}$ & $6.89 \pm 0.03$ & $6.91 \pm 0.04$ & $6.89 \pm 0.09$ & $6.95 \pm 0.02$ \\
\hline
\end{tabular}

Means within a row with the different superscript letters across rows are statistically different $p<0.05$. T1= Enzyme treated Prosopis pod meal, T2=untreated prosopis pod meal, T3= Lactobacillus plantarum inoculated prosopis pod meal, $\mathrm{T} 4=$ naturally inoculated prosopis pod meal. $\mathrm{G}(\mathrm{ml} / \mathrm{g} \mathrm{DM})$ : total gas produced corrected on dry matter basis; A: the asymptotic gas production; $\mathrm{B}$ : the time after incubation at which half of the asymptotic amount of gas has been formed; $\mathrm{C}$ : constant determining the sharpness of the switching characteristic of the profile; $T_{\text {MAX: }}$ : the time at which Rmax is accomplished; $R_{\text {MAX: }}$ the maximum rate of gas production $\left(\mathrm{ml} \mathrm{g}^{-1} \mathrm{xh}\right)$.

\section{Growth performance of the pigs}

The diets had a significant effect on FCR $(p<0.05)$ with D3 being significantly higher than the other treatments. The ADG was significantly $(p<0.05)$ highest for PC than the other diets. Higher inclusion levels of GPPM in the diet led to an increase in the FCR while pigs fed on PC (2.707) and D3 (3.383) had the lowest and the highest FCR respectively.

Diet significantly affected ADG ( $p<0.05)$ while sex did not affect the ADG ( $p=0.5554)$. The average daily gain of PC, NC and D1 were not significantly different. However, as the levels of inclusion of GPPM increased, the ADG of the pigs decreased with PC $(0.634 \mathrm{~kg} /$ day $)$ being significantly different from D2 $(0.440 \mathrm{~kg} /$ day $)$ and D3 $(0.420$ $\mathrm{kg} /$ day). Diet with $30 \%$ GPPM and enzyme had the lowest DFI and differed with T1, NC and D1 $(p<0.05)$.

Initial weight was not significantly different across all the experimental diets conversely, sex $(p=0.122)$ did not affect initial weight. Diet had a significant effect $(p<0.05)$ on the final weight of pigs (Table 5 ). Diet with $30 \%$ Prosopis pod meal and enzyme was significantly final weight lower compared to NC, however, D3 and D3 had similar final weight.

Table 5: Effect of experimental diets on growth performance of pigs 


\begin{tabular}{|llllllll|}
\hline Item & \multicolumn{2}{l}{ Dietary treatment } & & & & \multicolumn{3}{c|}{ P value } \\
\cline { 2 - 8 } & PC & NC & D1 & D2 & D3 & Diet & Sex \\
\hline ADG & $0.634 \pm 0.05^{\mathrm{a}}$ & $0.517^{\mathrm{ab}} \pm 0.07$ & $0.516^{\mathrm{b}} \pm 0.06$ & $0.440^{\mathrm{b}} \pm 0.04$ & $0.420^{\mathrm{b}} \pm 0.05$ & $<.0001$ & 0.55 \\
\hline FCR & $2.707^{\mathrm{a}} \pm 0.19$ & $2.833^{\mathrm{ab}} \pm 0.14$ & $3.058^{\mathrm{abc}} \pm 0.32$ & $3.275^{\mathrm{bc}} \pm 0.32$ & $3.383^{\mathrm{c}} \pm 0.33$ & 0.037 & 0.77 \\
\hline DFI & $1.467^{\mathrm{a}} \pm 0.05$ & $1.439^{\mathrm{ab}} \pm 0.05$ & $1.477^{\mathrm{a}} \pm 0.06$ & $1.330^{\mathrm{bc}} \pm 0.08$ & $1.271^{\mathrm{c}} \pm 0.04$ & $<.0001$ & 0.01 \\
\hline IW & $22.720 \pm 0.58$ & $21.593 \pm 0.89$ & $22.295 \pm 0.07$ & $22.405 \pm 0.80$ & $21.688 \pm 0.25$ & 0.525 & 0.12 \\
\hline FW & $40.950^{\mathrm{a}} \pm 0.95$ & $37.370^{\mathrm{b}} \pm 0.23$ & $37.580^{\mathrm{b}} \pm 0.42$ & $35.650^{\mathrm{c}} \pm 0.05$ & $34.470^{\mathrm{c}} \pm 0.68$ & 0.002 & 0.02 \\
\hline
\end{tabular}

Means within a row with the different superscript letters are statistically different $(p<0.05)$. Mean \pm SE.PC $=0 \%$ GPPM and $0.035 \%$ Enzyme per $\mathrm{kg}$ of diet; NC= 0\% GPPM and 0\% Enzyme per $\mathrm{kg}$ of diet; D1 $=10 \%$ GPPM and $0.035 \%$ Enzyme per $\mathrm{kg}$ of diet, D2 = 20\% GPPM and 0.035\% Enzyme per $\mathrm{kg}$ of diet, D3=30\% GPPM and $0.035 \%$ Enzyme per kg of diet; GPPM Ground Prosopis Pod meal. ADG = Average daily gain ( $\mathrm{kg} /$ day); DFI daily feed intake (kg); FCR feed conversion ratio, IW=initial weight $(\mathrm{kg})$, FW= final weight $(\mathrm{kg})$.

Weekly body weights were significantly different for the dietary treatments $(p<0.05)$. Pigs fed on diet D3 had a lower weekly weight relative to other pigs fed on the other diets for the whole feeding period (Figure 3).

\section{Discussion}

\section{Proximate analysis of the treated and untreated prosopis pod meal}

The chemical composition of GPPM were within the expected range reported by several authors (Sawal et al. 2004; King'ori et al. 2011; Manhique et al. 2019). The crude protein and ash content of the GPPM in the current study were however, higher than those reported by Manhique et al. (2019) even though GPPM were collected from the same locality. This could be due to the fact that samples from this study were mostly collected from communal grazing lands where local populations carried out livestock grazing. The presence of livestock in the silvo-pastoral systems contributes to a higher total carbon and nitrogen contents on the prosopis pod tree. This combined with agronomic activities causes a change in the nutritional contents of the various parts of the plant (King'ori et al. 2011; Lira et al. 2020). With regards to the relative importance of prosopis pod meal compared to other feed ingredients, GPPM contained a higher crude protein(14.48\%) than maize bran (11\%), maize grain (8.25\%), and industrial and kitchen swills (8.94-11.9\%) which are most common used feedstuffs for pig production in Kenya (Muthui et al. 2019). This indicates that GPPM contains a reasonable amount of protein and can be used in place of these ingredients.

Pre-treatment using Lactobacillus plantarum and natural fermentation resulted in a lower crude fibre (CF), NDF and ADF relative to the untreated. The decrease in fibre could be attributed to the hydrolysis of fibre constituents of the enzymatic activity of lactic acid bacteria that in conjunction with the lowering $\mathrm{pH}$ during the fermentation process released high lactic acid content in the sample. There is a good consensus that fermentation reduces the NDF content thus improving nutrient availability in feeds for pigs (Kraler et al. 2014; Koo et al. 2018). The 
results of this study corresponds to Wang et al. (2018) and Kuikui et al. (2014) who reported a decrease in the concentration of hemicellulose and NDF upon ensiling forages and wheat straw because of the acid hydrolysis and the ability of microbial enzymes released by microbes during ensiling to degrade the fibre.

On the other hand, pre-treatment using Lactobacillus plantarum or natural fermentation resulted in an increase in the concentration of crude protein as a result of the loss of organic carbon during fermentation. Indeed the values of organic matter from this study after fermentation did decrease compared to the untreated GPPM. Similarly (He et al. 2018) observed an improvement in CP after ensiling Neolamarckia cadamba leaves with and without lactobacillus inoculum.

\section{In-vitro dry matter digestibility}

Alternative feed resources are the predominant feed materials available for pigs in most parts of Kenya (Muthui et al. 2019). The quality of these alternative feeds depends on their nutrient content and the efficiency by which these feed resources are digested and utilized by pigs. However, due to the vastness of these materials in the tropics, it's impractical to investigate the digestibility of these materials on the actual animal as it is expensive and unethical. The utilization of in-vitro techniques to investigate digestibility, fermentation kinetics provides a viable approach to investigate various alternative feed resources and the various technologies that can be used to improve their utilization and their digestibility (Boisen and Fernández, 1997; Coles et al. 2005). The purpose of the first experiment was primarily to screen the three pre-treatment techniques for improving the digestibility of prosopis pod meal for further animal experiments.

The IVDMD of prosopis pod meal 49.1\% from this study was relatively lower thanthat of maizegrain $75.5 \%$ (Park et al. 2016). This could be attributed to high insoluble crude fiber content in the GPPM in comparison to maize. Consistently to the present study,(Al-Marzooqi et al. 2018) reported that despite having $3 \%$ more gross energy than corn, the apparent metabolizable energy of prosopis pod meal was reported to be $30 \%$ less than corn due to the high indigestible fiber content (83\%) in GPPM suggesting that utilization of prosopis pod meal is limited due to the high fiber. The addition of fibre degrading enzyme in this study led to an improvement in the in-vitro digestibility of dry matter of the GPPM by $3.68 \%$ compared to the control and by $2.51 \%$ and $7.21 \%$ respectively compared to Lactobacillus plantarum inoculated and naturally fermented GPPM. The multi enzyme complex used in this study had cocktail of fibroytic (xylanase, cellulose and beta-glucanase) enzyme that potentially had an improvement in fibredegradability. These enzymes have been postulated to cause disruption and hydrolysis of the plant cell wall integrity and consequently led to release of nutrients encapsulated by the cell wall constituents (de Vries et al. 2012). As a result, more nutrients were made available for digestion by gastric and pancreatic enzymes (Lee et al. 2018). This could explain the increase in digestibility and cumulative gas production on enzyme treated GPPM.

Results of fermentation using Lactobacillus plantarum (T3) improved the IVDMD by $1.2 \%$ compared to the untreated GPPM, while on the other hand natural fermentation (T4) decreased IVDMD by $3.5 \%$ relative to the untreated GPPM. Contrary, to the present study Jørgensen et al. (2010) reported that the ileal digestibility of dry matter after natural fermentation of barley and wheat increased by 6 and 3 percentage units, respectively. The differences in the amount of starch in prosopis pod meal compared to barley and wheat could explain the differences. Barley and wheat contain a higher amount of starch composition $64.8 \%$ and $69.5 \%$ respectively which are rendered more digestible upon fermentation (Zentek \& Boroojeni, 2020). The higher ileal digestibility of 
barley and wheat could therefore be as a result of increased starch digestibility. This is unlike prosopis pods meal that contains a tiny amount of starch as most of the carbohydrates present are majorly free sugars, saccharose (20-25\% DM) and reducing sugars (10-20\% DM) (Choge et al. 2007), that are usually rapidly lost during the fermentation process. However, this could not explain the lower IVDMD of natural fermentation compared to Lactobacillus plantarum observed in this study. This could probably be explained by the lower carbohydrates and organic matter that was as a result of natural fermentation. In fact, from this study, natural fermentation had a slightly lower organic matter content than Lactobacillus Plantarum fermented GPPM (93.96 vs $94.15 \%)$. Natural fermentation also regarded as spontaneous fermentation is an unreliable type of fermentation as consequence, it is associated with higher nutrient losses due to the longer time it takes to achieve a lower $\mathrm{pH}$ that inhibit growth of organism, such as yeast and clostridia ,associated with loss of organic matter through $\mathrm{CO}_{2}$ production (Huyen et al. 2020). It is therefore, possible that naturally fermented prosopis pod meal had less organic matter and sugars available during pepsin-pancreatine digestion thus the low digestibility. On the contrary, fermentation that uses inoculants such as Lactobacillus plantarum is usually associated with less organic matter loss and dry matter loss (Li et al. 2020). This is consistent with Tabacco et al. (2011) who reported a reduction in the dry matter lossafter ensiling forage crop treated Lactobacillus treatment, relative to untreated silage.

\section{Fermentation kinetics}

Enzyme supplementation exhibited fast and intense fermentation patterns with the highest cumulative gas productions and rate of fermentation (Rmax) and the lowest time to reach Rmax (Tmax). This due to the capacity of the ability of multi-enzyme to breakdown fiber in to short fragments that were highly fermentable by microorganisms in the hindgut of pigs (Woyengo et al. 2016). In contrast, both fermentation (T4) and (T3) did not result in an improvement in cumulative gas production compared to the control. Additionally, the rate of gas produced (Rmax) in natural and inoculated fermentation was significantly lower compared to the control this is despite the lower amount of crude fibre associated with fermentation. As mentioned earlier pre-treatment using fermentation could have led to losses of some rapidly fermentable carbohydrates including the saccharose, soluble non-starch polysaccharides and reducing sugars present in the prosopis pod meal as evident by the reduction of the total carbohydrates, hemicellulose and increased ash. Indeed, with hemicellulose values of $18.15 \%$, and $16.90 \%$ for lactobacillus inoculated fermentation and natural fermentation respectively, fermentation of prosopis pod meal did not supply more highly fermentable hemicellulose than the enzyme pretreated and untreated GPPM diet at $20.28 \%$. These rapidly fermentable components are usually the first to be hydrolysed or used up to provide energy during microbial fermentation (Koo et al.2018). This, therefore meant that the residues subjected to the hindgut fermentation comprised of slowly fermentable and non-fermentable components whose rate of degradation was lower. Similarly, Ferrer et al. (2021) reported a decrease in soluble organic components (sugars and soluble fibre) while ash and insoluble fibrous content increased as a result of the fermentation of dried orange pulp.

\section{Production performance of grower pigs}

Feed intake is influenced by many factors including animal characteristics such as body weight, genetic adaptations, and feed factors such as nutrients density, digestibility, and the presence of anti-nutritive factors (Choct et al. 2010). Similarly, factors that affect feed intake also influence feed conversion ratio. In this study, there was a significant decrease in feed intake and a reduction in feed efficiency as measured by increasing FCR

Page $14 / 22$ 
when GPPM was included at 30\%+ enzyme (D3) a diet with 371.3g/kg DM NDF and $169.40 \mathrm{~g} / \mathrm{kg}$ DM ADF. Several reasons could have contributed to the reduced feed intake and feed efficiency. Firstly, the physical characteristics of prosopis pod meal is usually highly fibrous with high amount of ADF and NDF. Diets with a high amount of fibre are associated with an increased bulkiness in the gut and thus reduces feed intake (Ndou et al. 2014). Further, the high amount of insoluble fibre could have led to increased water holding capacity (as most of these insoluble fibres such as cellulose behave like sponges within the gastrointestinal tract) that eventually lead to gut fill, thus depressing feed intake (Ndou et al. 2014; Jang et al. 2019). Our results corresponds to (Ndou et al. 2014) who reported that the gut capacity was attained when weaners pigs were offered a diet containing an NDF of $367 \mathrm{~g} / \mathrm{kg}$ DM and ADF of $138 \mathrm{~g} / \mathrm{kg} \mathrm{DM}$ above which feed intake starts to reduce. It is interesting to note that values for NDF and ADF of the diet with 30\% GPPM had surpassed the values by (Ndou et al. 2014) where feed intake starts decreasing. However, this could not in entirety explain the decrease in feed conversion ratio and feed intake as the effect of fibre on gut fill diminishes as the pig ages (Ndou et al. 2014). Therefore, other factors such as the level of tannins could have resulted in decreased feed intake. Although effects on tannins found in prosopis pod on performance were not investigated, tannins are usually bitter and astringent, and thus affects feed intake (Odero-Waitituh et al. 2016). In fact, tannins have been attributed to reduced dietary protein digestibility (Annor et al. 2017) as a result of their ability to form insoluble complexes with both digestive enzymes and dietary protein thus reducing feed conversion ratio. The low feed intake and feed efficiency from this study are consistent with (Pinheiroer et al.1993) who reported a significant reduction in feed intake and feed conversion when prosopis pod meal replaced the $30 \%$ maize soybean mixture of fatteners pigs. Other authors have also reported that nutrient intakes were depressed in animals that consumed diets containing more than $200 \mathrm{~g} / \mathrm{kg}$ of Prosopis Juliflora pods due to large amounts fiber and tannins that suppressed feed intake(Abdullah and Abddel,2004;Obeidat et al. 2008;Odero-Waitituh et al. 2016).

Results from the average daily gain (ADG) of NC (Control without enzyme) compared to D1 10\%, D2-20\%, and D3-30\%were not significantly different though there was a decrease in the feed intake as the level of GPPM increased across the diets. This is in contrast to (Pinheiroer et al. 1993) who reported a reducing ADG as prosopis gradually replace a maize-soybean mixture in the diet of finishing pigs, at a $30 \%$ level of inclusion.A number of reasons could explain this, first as evident from the in-vitro trial multi enzyme complex increases IVDMD of prosopis pod meal. This is due to the fact that multi-enzyme mixtures have been known to improve the digestibility of protein, energy and fats by reducing the viscosity of the digesta and hydrolysing the nonstarch polysaccharides (Torres-Pitarch et al. 2017). This increases the contact between the feed and digestive enzymes as well as the digestive surfaces. Secondly, the addition of multi-enzyme has been reported to improve fibre digestibility as a result of fermentation of the fibre in the hindgut with the volatile fatty acids produced contributing to the net energy requirements of the pigs needed for growth (Nkosi, et al. 2020). This could therefore explain why the inclusion of prosopis pod meal up to $30 \%$ of the diet had no negative effect on growth rate as the enzyme probably counteracted the effects of increasing fibre in the diets. Similarly, Kwon et al. (2020) reported higher inclusion levels of palm kernel meal (PKM) for growing-finishing pigs of $12 \%$ compared to a conservative recommended inclusionlevel of $10 \%$ due to supplementation of $\beta$-mannanase enzyme to diets containing PKM.

The addition of enzyme to the diet without GPPM (PC) compared to NC (without the enzyme and GPPM) did not result in an improvement in ADG. This was expected since PC and NC had met the nutrients requirements of pigs whilst having minimal fibre content. The growth of animals fed these diets reached the commercial

Page $15 / 22$ 
expectation, andthus, significant improvement by multi-enzyme over that which had already been achieved would have been unlikely. This finding is consistent with other studies (e.g. I'Ansonet al. 2014;Nkosi et al. 2020) who reported that the extent to which enzyme supplementation improves nutrient digestibility tends to be low when using highly digestible ingredients thus improvement in growth rates are not observed.

In conclusion, based on this study, pre-treatment of prosopis pod with exogenous enzyme improved in-vitro digestibility compared to untreated, natural and Lactobacillus plantarum induced-fermentation while cumulative gas produced improved slightly though not significant. Naturally fermented prosopis pod meal however results in low digestibility and fermentability therefore, it is not a suitable pre-treatment method for improving the digestibility of the pods for pigs. Further, overall feed efficiency (as measured by FCR) and feed intake decreased at 30\% + enzyme GPPM however, growth rates remained unaffected at these levels. The study demonstrated that prosopis pod meal with the multi-enzyme complex can be included up to $30 \%$ in grower's pig diets without effects to average daily weight gain.

\section{Declarations}

\section{Acknowledgement}

Authors wish to thank ManiTese Italian Non-Governmental Organization through the Network for Eco-Farming in Africa (NECOFA) for funding this research.

\section{Statement of Animal Rights}

The materials and procedures of this study had been approved by approved by Egerton University Research Ethics Committee with approval No. EUREC/APP/109/2021 and National Commission of Science and Technology of Kenya under the permit No: NACOSTI/P/20/6926.

\section{Conflicts of interest}

Authors state they have no conflicts of interest.

\section{Funding Information}

Funding from ManiTese Italian Non-Governmental Organization through Network ForEco Farming in Africa was greatly appreciated.

\section{Consent for Participation}

Not applicable

\section{Consent to publish}

Not applicable

\section{Data Availability}


The datasets generated during and/or analysed during the current study are available from the corresponding author on reasonable request.

\section{Code availability}

Not applicable

\section{Authors' contribution}

All authors contributed to the study from conception and design. Material preparation, data collection and analysis were performed by Ngugi David, Olivier Kashongwe and Anthony King'ori. The first draft of the manuscript was written by Ngugi David and all authors read and approved the manuscript.

\section{References}

1. Abdullah, A.Y \& Abddelhafes, B.Y. (2004). Inclusion of Prosopis juliflorapods in finishing Awassi lamb diets. In:Proc. 11th AAAP Animal Science Congress, vol. 2, pp. 373-375.

2. Annor, G. A., Tyl, C., Marcone, M., Ragaee, S \& Marti, A. (2017). Why do millets have slower starch and protein digestibility than other cereals? Trends in Food Science \& Technology, 66, 73-83.

3. Association of Official Analytical Chemists International (AOAC) (1990). Official Methods of Analysis, 15th edn Pp. 1028- 1039. Arlington, VA: Association of Official Analytical Chemists Inc.

4. Al-Marzooqi, W., Al-Kharousi, K., Kadim, I. T., Mahgoub, O., Zekri, S., Al-Maqbaly, R \& Al-Busaidi, M. (2015). Effects of feeding prosopis juliflora pods with and without exogenous enzyme on performance, meat quality and health of broiler chickens. International Journal of Poultry Science, 14(2), 76-88.

5. Bauer, E., Williams, B. A., Voigt, C., Mosenthin, R \& Verstegen, M. W. A. (2001). Microbial activities of faeces from unweaned and adult pigs, concerning selected fermentable carbohydrates. Animal Science, 73(2), 313-322.

6. Bindelle, J., Buldgen, A., Boudry, C \& Leterme, P. (2007). Effect of inoculum and pepsin-pancreatin hydrolysis on fibre fermentation measured by the gas production technique in pigs. Animal Feed Science and Technology, 132(1-2), 111-122.

7. Boisen, S \& Fernández, J. A. (1997). Prediction of the total tract digestibility of energy in feedstuffs and pig diets by in-vitro analyses. Animal Feed Science and Technology, 68(3-4), 277-286.

8. Choct, M., Dersjant-Li, Y., McLeish, J \& Peisker, M. (2010). Soy oligosaccharides and soluble non-starch polysaccharides: A review of digestion, nutritive and anti-nutritive effects in pigs and poultry. AsianAustralasian Journal of Animal Sciences, 23(10), 1386-1398.

9. Choge, S.K., Pasiecznik, N.M., Harvey, M., Wright, J., Awan, S.Z \& Harris, P.J.C., 2007. Cooking with Prosopis flour. Recipes tried and tested in Baringo District, Kenya. KEFRI, Nairobi, Kenya and HDRA, Coventry, UK, 6pp

10. Choge, S. K., Pasiecznik, N. M., Harvey, M., Wright, J., Awan, S. Z \& Harris, P. J. C. (2007).Prosopis pods as human food, with special reference to Kenya. Water SA, 33(3 Special edition), 419-424

11. Coles, L. T., Moughan, P. J \& Darragh, A. J. (2005). In vitro digestion and fermentation methods, including gas production techniques, as applied to the nutritive evaluation of foods in the hindgut of humans and other simple-stomached animals. Animal Feed Science and Technology, 123, 421-444. 
12. de Vries, S., Pustjens, A. M., Schols, H. A., Hendriks, W. H \& Gerrits, W. J. J. (2012). Improving digestive utilization of fibre-rich feedstuffs in pigs and poultry by processing and enzyme technologies: A review. Animal Feed Science and Technology, 178(3-4), 123-138.

13. Ferrer, P., García-Rebollar, P., Calvet, S., de Blas, C., Piquer, O., Rodríguez, C. A \& Cerisuelo, A. (2021). Effects of Orange Pulp Conservation Methods (Dehydrated or Ensiled Sun-Dried) on the Nutritional Value for Finishing Pigs and Implications on Potential Gaseous Emissions from Slurry. Animals, 11(2), 387

14. Groot, J. C. J., Cone, J. W., Williams, B. A., Debersaques, F. M. A \& Lantinga, E. A. (1996). Multiphasic analysis of gas production kinetics for in vitro fermentation of ruminant feeds. Animal Feed Science and Technology, 64(1), 77-89.

15. He, L., Zhou, W., Wang, Y., Wang, C., Chen, X \& Zhang, Q. (2018). Effect of applying lactic acid bacteria and cellulase on the fermentation quality, nutritive value, tannins profile and in vitro digestibility of Neolamarckiacadamba leaves silage. Journal of animal physiology and animal nutrition, 102(6), 14291436.

16. Huyen, N. T., Martinez, I \& Pellikaan, W. (2020). Using lactic acid bacteria as silage inoculants or direct-fed microbials to improve in vitro degradability and reduce methane emissions in dairy cows. Agronomy, 10(10), 1482.

17. I'Anson, K. A., Choct, M., \& Brooks, P. H. (2014). Effects of dietary xylanase and liquid feeding on growth performance and nutrient digestibility of weaner pigs fed diets high in millrun (wheat by-product). Animal Production Science, 54(7), 972-980.

18. Jang, J. C., Javaid, A., Urriola, P. E., \& Shurson, G. C. (2021). Effect of Exogenous Enzyme Supplementation and Fermentation of Oilseed By-products on in vitro Digestibility and Production of Short Chain Fatty Acid. Journal of Animal Science, 99(Supplement_1), 79-79.

19. Jørgensen, H., Sholly, D., Pedersen, A. Ø., Canibe, N \& Knudsen, K. E. B. (2010). Fermentation of cereals Influence on digestibility of nutrients in growing pigs. Livestock Science, 134(1-3), 56-58.

20. Kagira, J. M., Kanyari, P. W. N., Maingi, N., Githigia, S. M., Ng'ang'a, J. C \& Karuga, J. W. (2010). Characteristics of the smallholder free-range pig production system in western Kenya. Tropical Animal Health and Production, 42(5), 865-873.

21. Kambashi, B., Picron, P., Boudry, C., Théwis, A., Kiatoko, H \& Bindelle, J. (2014). Nutritive value of tropical forage plants fed to pigs in the Western provinces of the Democratic Republic of the Congo. Animal Feed Science and Technology, 191, 47-56.

22. King'ori, A. M., Odero-Waitituh, J. A. and Guliye, A. Y. (2011). Mathenge(Prosopis juliflora): An underutilized Livestock Feed Resource in Kenya. Research Journal of Animal Sciences, 5(4-6): 43-51.

23. Koo, B., Kim, J. W \& Nyachoti, C. M. (2018). Nutrient and energy digestibility, and microbial metabolites in weaned pigs fed diets containing Lactobacillus-fermented wheat. Animal Feed Science and Technology, 241, 27-37.

24. Kraler, M., Schedle, K., Domig, K. J., Heine, D., Michlmayr, H \& Kneifel, W. (2014). Effects of fermented and extruded wheat bran on total tract apparent digestibility of nutrients, minerals and energy in growing pigs. Animal Feed Science and Technology, 197, 121-129.

25. Kwon, W. B \& Kim, B. G. (2015). Effects of supplemental beta-mannanase on digestible energy and metabolizable energy contents of copra expellers and palm kernel expellers fed to pigs. Asian-Australasian 
journal of animal sciences, 28(7), 1014.

26. Kuikui Ni., Wang, Y., Pang, H., \& Cai, Y. (2014). Effect of cellulase and lactic acid bacteria on fermentation quality and chemical composition of wheat straw silage. American Journal of Plant Sciences, 2014.

27. Lee, J. W., Patterson, R \& Woyengo, T. A. (2018). Porcine in vitro degradation and fermentation characteristics of canola co-products without or with fibre-degrading enzymes. Animal Feed Science and Technology, 241, 133-140.

28. Li, F., Ding, Z., Adesogan, A. T.,Ke, W., Jiang, Y., Bai, J \& Guo, X. (2020). Effects of Class IlaBacteriocinProducing Lactobacillus Species on Fermentation Quality and Aerobic Stability of Alfalfa Silage. Animals, 10(9), 1575.

29. Lira Junior, M. A., Fracetto, F. J. C., Ferreira, J. da S., Silva, M. B \& Fracetto, G. G. M. (2020). Legume silvopastoral systems enhance soil organic matter quality in a subhumid tropical environment. Soil Science Society of America Journal, 84(4), 1209-1218.

30. Lyberg, K., Lundh, T., Pedersen, C \& Lindberg, J. E. (2006). Influence of soaking, fermentation and phytase supplementation on nutrient digestibility in pigs offered a grower diet. Animal Science, 82, 853-858.

31. Manhique, A O., Kingori, A. M \&. Khobondo, J. (2019). Effect of incorporation of ground Prosopis juliflora pods in layer diet on weight gain, egg production, and natural antibody titer in KALRO genetically improved indigenous chicken. Tropical Animal Health and Production, 51(8), 2213-2218.

32. Mbuthia, J. M., Rewe, T. O \& Kahi, A. K. (2014). Breeding objectives for pigs in Kenya. Il: economic values incorporating risks in different smallholder production systems. Tropical Animal Health and Production, $47(2), 361-367$.

33. Menke, K. H., Raab, L., Salewski, A., Steingass, H., Fritz, D \& Schneider, W. (1979). The estimation of the digestibility and metabolizable energy content of ruminant feedingstuffs from the gas production when they are incubated with rumen liquor in-vitro. The Journal of Agricultural Science, 93(1), 217-222.

34. Muthui (2019). Influence of Nutrition and Value Chain Governance on Enterprise Performance in Smallholder Pig Production in Kenya. Doctoral dissertation, Egerton University.

35. Ndou, S., Gous, R., \& Chimonyo, M. (2013). Prediction of scaled feed intake in weaner pigs using physicochemical properties of fibrous feeds. British Journal of Nutrition, 110(4), 774-780.

36. Nkosi, B. D., Seshoka, M. L., Fourie, P. J., Kanengoni, A. T., Malebana, I. M. M \& Thomas, R. S. (2020). Dietary enzyme addition on the growth performance and carcass characteristics of pigs fed diets containing avocado oil cake silage. Tropical Animal Health and Production, 52, 2945-2953

37. NRC. (2012). Nutrient Requirements of Swine. Nutrient Requirements of Swine.

38. Odero-Waitituh, J. A., King'ori, A. M \& Guliye, A. Y. (2016). Effect of replacing maize with milled mature pods of prosopis juliflora on performance of finishing broiler chicken. Livestock Research for Rural Development, 28(2).

39. Odero-Waitituh, J. A., Kingori, A. M \& Ambula, M. K. (2020). Bio-economic Implications of Feeding Fermented Ground Mature Prosopis Juliflora Pods to Grower Rabbits. Journal of Economic Impact, 2(2), 4349.

40. Park, K. R., Park, C. S \& Kim, B. G. (2016). An enzyme complex increases in-vitro dry matter digestibility of corn and wheat in pigs. Springerplus, 5(1), 1-7. 
41. Pinheiro, MJP, de Sousa, RP \& Espíndola, GB (1993). Effects of adding mesquite pod meal to pigs in the finishing phase. PesquisaAgropecuáriaBrasileira, 28 (12), 1443-1449.

42. TabaccoE., Righi F., QuarantelliA \& Borreani.G. (2010). Dry matter and nutritional losses during aerobic deterioration of corn and sorghum silages as influenced by different lactic acid bacteria inocula. Journal of Dairy Science. 94:1409-1419.

43. Torres-Pitarch, A., Hermans, D., Manzanilla, E. G., Bindelle, J., Everaert, N., Beckers, Y \& Lawlor, P. G. (2017). Effect of feed enzymes on digestibility and growth in weaned pigs: A systematic review and meta-analysis. Animal Feed Science and Technology, 233, 145-159.

44. Van Soest, P. J., Robertson, J. B \& Lewis, B. A. (1991). Methods for Dietary Fiber, Neutral Detergent Fiber, and Nonstarch Polysaccharides in Relation to Animal Nutrition. Journal of Dairy Science, 74(10), 3583-3597.

45. Wang, S., Guo, G., Li, J., Chen, L., Dong, Z \& Shao, T. (2018). Improvement of fermentation profile and structural carbohydrate compositions in mixed silages ensiled with fibrolytic enzymes, molasses and Lactobacillus plantarum MTD-1. Italian Journal of Animal Science, 18(1), 328-335.

46. Woyengo T. A., Jha R., Beltranena. E \& Zijlstra R. T. (2016).In vitro digestion and fermentation characteristics of canola co-products simulate their digestion in the pig intestine. Animal, 10(6), 911-918.

47. Zangaro, C. A., Patterson \&Woyengo, T. A. (2019). Porcine in vitro digestion and fermentation characteristics of corn wet distillers' grains and dried distillers grains with solubles without or with multi-enzyme. Animal Feed Science and Technology, 254, 114205.

48. Zentek, J \&Boroojeni, F. G. (2020). (Bio) Technological processing of poultry and pig feed: Impact on the composition, digestibility, anti-nutritional factors and hygiene. Animal Feed Science and Technology, 268, 114576.

\section{Figures}

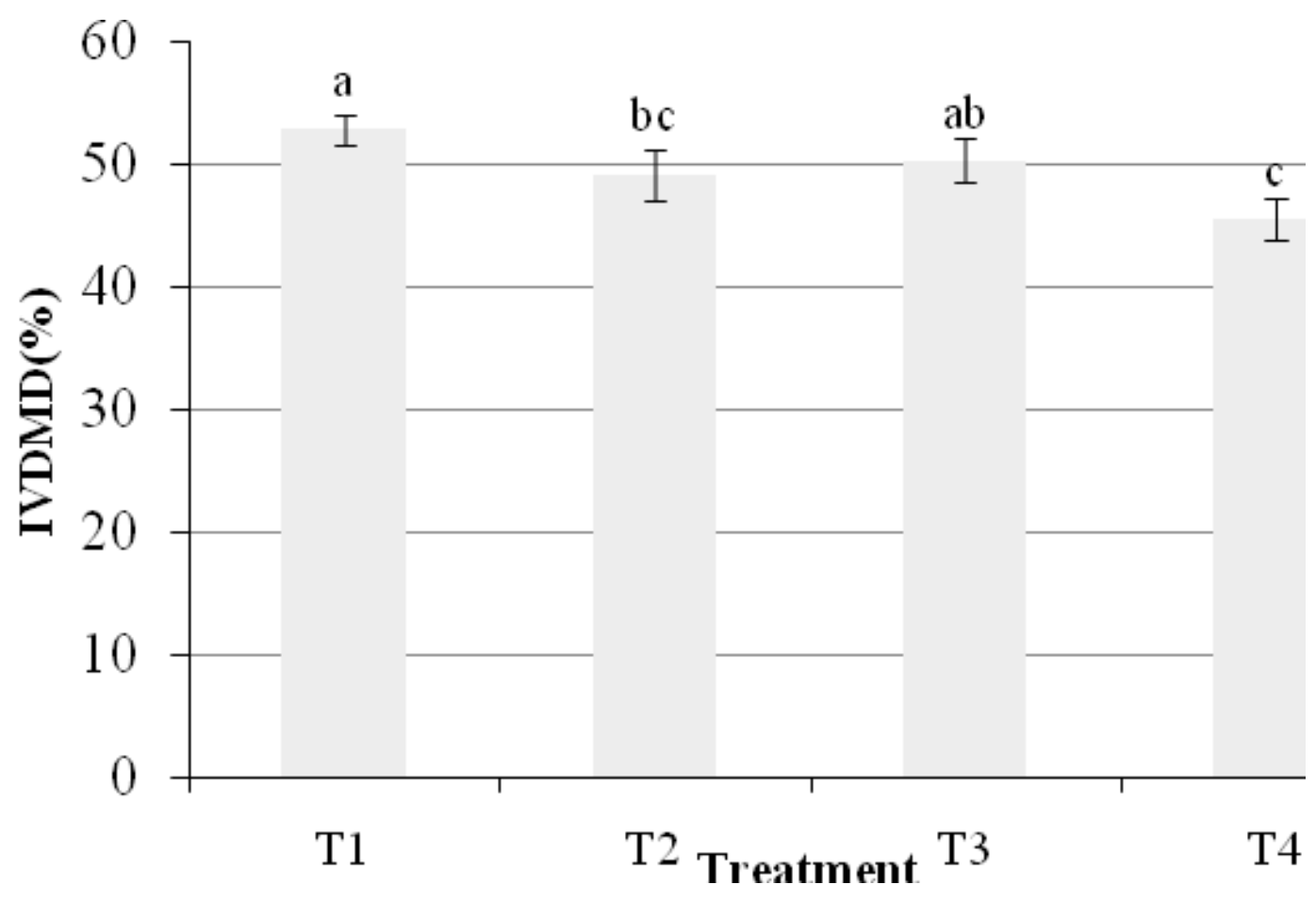


In-vitro digestibility of multi-enzyme, fermented and untreated ground Prosopis pod meal. Error bar represents Mean ( \pm SE) In-vitro dry matter digestibility of GPPM. T1= Multi-enzyme treated GPPM, T2=untreated GPPM, T3= Lactobacillus plantarum-MTD1 (Ecosyl®) inoculated GPPM, T4= naturally fermented GPPM.

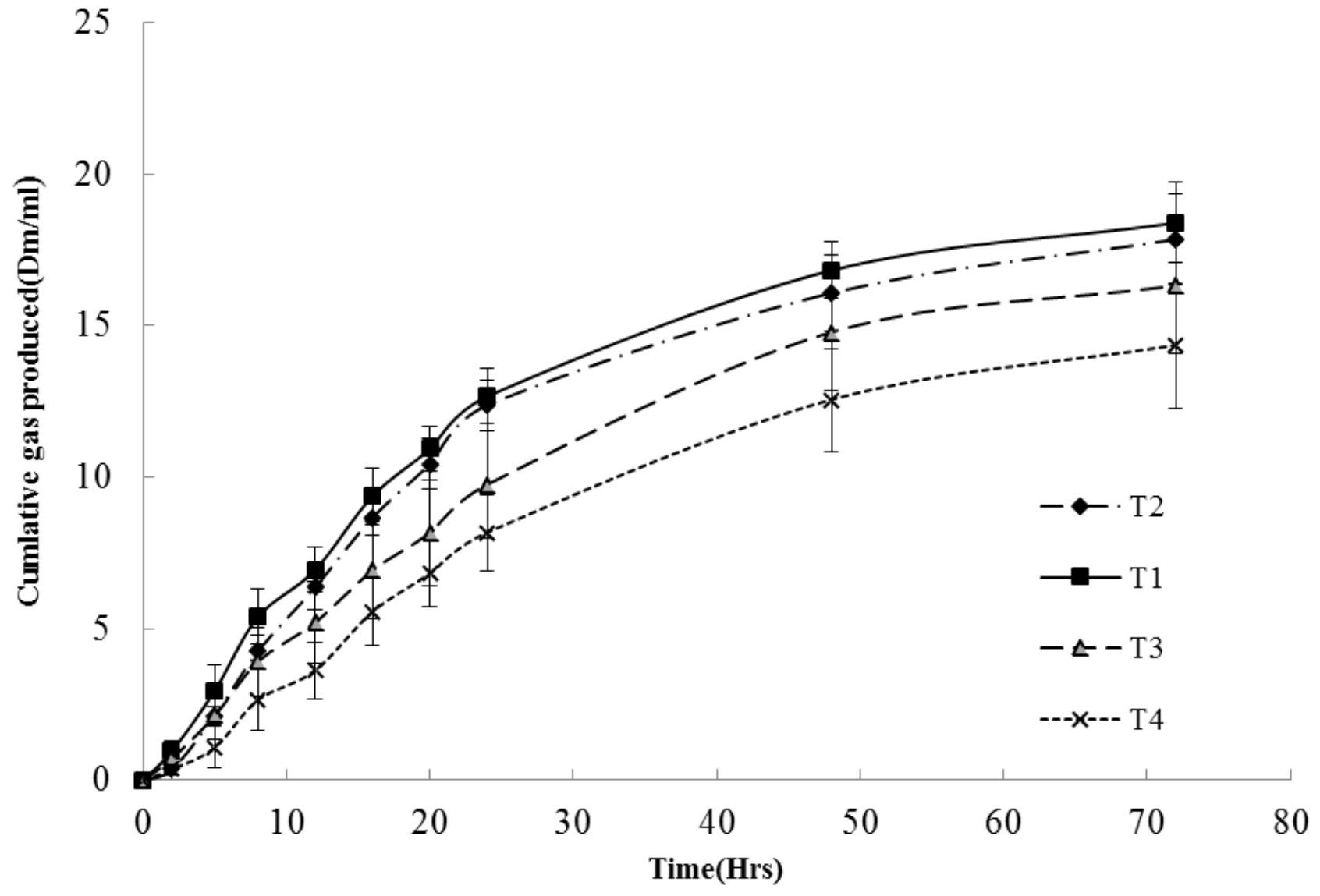

Figure 2

Fitted gas accumulation curves modelled using the mathematical formula described by Groot et al. (1996) that show the amount of gas produced in $\mathrm{mL}$ per gram of $\mathrm{DM}$ and accumulated during the indicated time period in study. T1 = Enzyme-treated prosopis pod meal, T2=untreated prosopis pod meal, T3= Lactobacillus plantarum inoculated prosopis pod meal, T4= naturally inoculated prosopis pod meal. Error bars indicate \pm SE. 


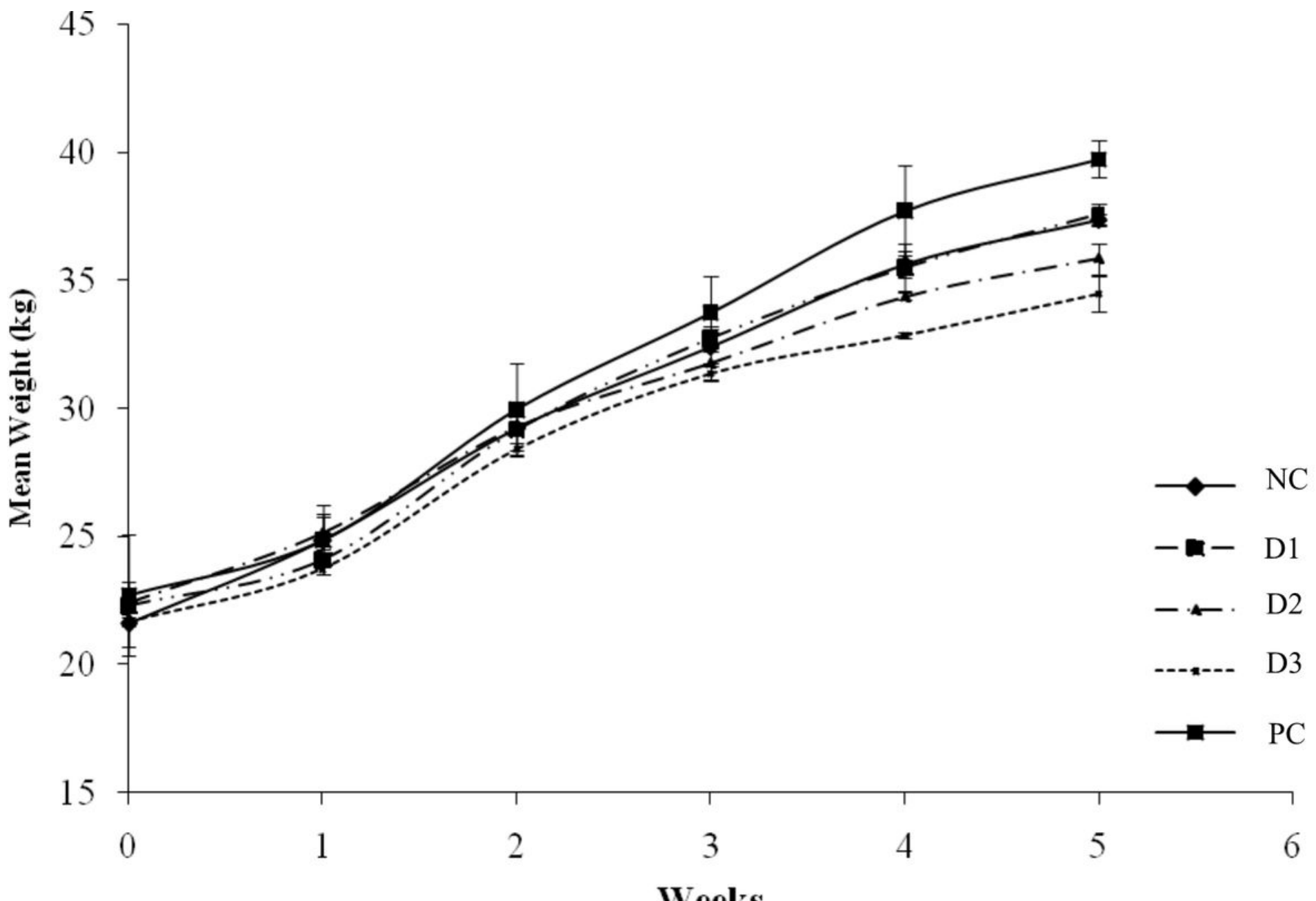

Figure 3

Mean weekly weight of pigs fed diets with or without prosopis meal and Natuzyme $\circledast$. PC $=0 \%$ GPPM and $0.035 \%$ Enzyme per $\mathrm{kg}$ of diet; NC= 0\% GPPM and 0\% Enzyme per $\mathrm{kg}$ of diet; D1 $=10 \%$ GPPM and $0.035 \%$ Enzyme per $\mathrm{kg}$ of diet, D2 = 20\% GPPM and 0.035\% Enzyme per kg of diet, D3= 30\% GPPM and 0.035\% Enzyme per $\mathrm{kg}$ of diet. Error bars indicate \pm Standard 